\title{
PENGARUH STRATEGI PEMBELAJARAN DISCOVERY TERHADAP KEMAMPUAN BERPIKIR KRITIS SISWA PADA MATA PELAJARAN IPA KELAS VIII DI SMPN 3 GUNUNGSARI TAHUN AJARAN 2014/2015
}

\author{
Zaetun Zakrah $^{1)}$, Nur Lestari ${ }^{2)}$, Kusmiyati $^{3)}$ \\ ${ }^{1)}$ Mahasiswa Pendidikan Biologi FKIP Universitas Mataram \\ ${ }^{2)}$ 3) Dosen Pendidikan Biologi FKIP Universitas Mataram \\ Universitas Mataram, Jalan Majapahit No.62, Mataram \\ Email: zaetun_zakrah@yahoo.co.id
}

\begin{abstract}
$\overline{\text { Abstrak: Dalam pembelajaran IPA di sekolah diharapkan guru lebih menekankan pada pemberian pengalaman }}$ belajar secara langsung melalui penggunaan dan pengembangan keterampilan proses serta sikap ilmiah, untuk mengembangkan kompetensi sebagai aspek penting kecakapan hidup, sehingga pembelajaran IPA dapat menjadi wahana bagi peserta didik untuk mempelajari diri sendiri dan alam sekitar. Oleh karena itu diperlukan suatu strategi pembelajaran yang berorientasi pada peserta didik (student centered), salah satunya adalah strategi pembelajaran discovery. Penelitian ini bertujuan untuk mengetahui pengaruh strategi pembelajaran discovery terhadap kemampuan berpikir kritis siswa pada mata pelajaran IPA di SMP Negeri 3 Gunungsari Tahun Ajaran 2014/2015. Penelitian ini merupakan penelitian eksperimen semu dengan desain nonequivalen control group desain. Populasi dalam penelitian ini adalah seluruh siswa kelas VIII yang terbagi dalam lima kelas, dengan menggunakan teknik cluster random sampling diperoleh sampel kelas VIIIA sebagai kelas eksperimen dan kelas VIIIB sebagai kelas kontrol. Penelitian ini telah dilaksanakan di SMPN 3 Gunungsari pada tanggal 28 Oktober sampai tanggal 18 November Tahun 2014. Instrumen penelitian terdiri dari tes kemampuan berpikir kritis, lembar observasi aktivitas siswa, dan lembar observasi aktivitas guru. Data penelitian dianalisis menggunakan uji hipotesis yaitu uji-t polled varians pada taraf signifikan 5\%. Hasil penelitian menunjukkan bahwa nilai ratarata keterampilan berpikir kritis kelas eksperimen lebih tinggi dari kelas kontrol $(73,7>65,8)$. Hasil uji hipotesis menunjukkan bahwa $t$ hitung lebih besar daripada $t$ tabel $\left(t_{h i t} 3,21>t_{\text {tab }} 2,02\right)$. Maka dapat disimpulkan bahwa strategi pembelajaran discovery berpengaruh terhadap kemampuan berpikir kritis siswa pada mata pelajaran IPA kelas VIII SMPN 3 Gunungsari Tahun Ajaran 2014/2015.
\end{abstract}

\section{Kata kunci: $\quad$ Strategi Pembelajaran Discovery, Keterampilan Berpikir Kritis}

Abstract: Natural science instruction in school, teachers are expected to put more emphasize on the provision of direct learning experience through the use and development of process skills and scientific attitude, to develop competence as an important aspect of life skills, so that learning science could be vehicle for students to learn about themselves and the nature around. Therefore, needful learning strategy oriented to students, one of which is a discovery learning strategy. This study aims to determine the effect of discovery learning strategy to students' critical thinking skills in science in the SMPN 3 Gunungsari Academic Year 2014/2015. This study was a quasi-experimental research design with nonequivalen control group design. The population of this study were all students at grade VIII which divided into five classes, using cluster random sampling technique was obtained sample class as a class experiment VIIIA and VIIIB class as the control class. This research was conducted at SMPN 3 Gunungsari, in October to November 2014. The research instrument consisted of a test of critical thinking skills, observation of student activity sheets, and teacher observation sheet activities. Data were analyzed using hypothesis testing polled variance t-test at 5\% significance level. The results indicating that the average value of critical thinking skills experimental class is higher than the control class (73.7> 65.8). Hypothesis test results indicating that $t$-test is higher than $t$-table ( $\left.t_{\text {count }} 3,21>t_{\text {table }} 2,02\right)$, so it can be concluded that the discovery learning strategies having an effect on students' critical thinking skills in natural science instruction in class VIII SMP 3 Gunungsari academic year 2014/2015

\section{Keywords: $\quad$ Discovery Learning Strategy, Critical Thinking Skills}

\section{PENDAHULUAN}

Potensi sumber daya manusia merupakan aset nasional sekaligus sebagai modal dasar pembangunan bangsa. Potensi ini hanya dapat digali dan dikembangkan serta dipupuk secara efektif melalui startegi pendidikan dan pembelajaran yang terarah dan terpadu, yang dikelola secara serasi dan seimbang dengan memperhatikan pengembangan potensi peserta didik secara utuh dan optimal [1].

Pembelajaran merupakan suatu sistem instruksioal yang mengacu pada seperangkat komponen yang saling bergantung satu sama lain untuk mencapai tujuan. Selaku suatu sistem, pembelajaran meliputi suatu komponen, antara lain tujuan, bahan, peserta didik, guru, metode, situasi dan evaluasi, sedangkan strategi pembelajaran 
adalah cara yang digunakan untuk mengimplementasikan rencana yang sudah disusun dalam kegiatan nyata agar tujuan yang telah disusun tercapai secara optimal [2], agar tujuantujuan pembelajaran yang diinginkan tercapai secara efektif dan efisien, maka perlu dikembangkan suatu strategi pembelajaran yang tepat, sehingga memberikan kesempatan kepada siswa untuk bertukar pendapat, bekerjasama dengan teman, berinteraksi dengan guru, menggunakan maupun mengingat konsep yang dipelajari. Mengingat bahwa peserta didik memiliki karakteristik yang berbeda baik dari segi kecakapan, kecerdasan, minat, bakat dan kreativitas, dengan demikian guru hendaknya menggunakan strategi yang sesuai dengan materi yang diajarkan sehingga akan mempermudah guru untuk menyampaikan materi yang diajarkannya, demikian juga dengan peserta didik akan lebih mudah dalam menyerap pelajaran dan dapat membangkitkan minat dan motivasi dari peserta didik.

Berdasarkan hal tersebut guru memerlukan strategi pembelajaran yang dapat membuat peserta didik dapat aktif dan mengembangkan kemampuan berpikir kritisnya di kelas. Selain itu guru juga harus mengembangkan strategi pembelajaran dimana peserta didik ikut mengambil bagian dalam pembelajaran tersebut sehingga bukan hanya guru saja yang lebih mendominasi pembelajaran. Sejalan dengan pendapat Sopiatin [3], bahwa "proses belajar mengajar dapat berjalan efektif jika siswa diberi kesempatan untuk belajar secara aktif dan dikelola dengan baik". Salah satu strategi pembelajaran yang berkembang saat ini adalah strategi pembelajaran discovery. Menurut Sund dalam [4], menyatakan bahwa "discovery ialah proses mental dimana siswa/individu mengasimilasikan konsep dan prinsip-prinsip". Peserta didik diberi kesempatan oleh pendidik dalam mengembangkan potensi yang dimilikinya.

Menurut pernyataan Brunner dalam [5], menyatakan bahwa "belajar penemuan mengakibatkan keingintahuan siswa, memberikan motivasi untuk bekerja terus sampai menemukan jawaban-jawaban". Pendekatan ini dapat mengajarkan keterampilan- keterampilan memecahkan masalah tanpa pertolongan seseorang dan meminta pada siswa untuk menganalisis dan memanipulasi pengetahuan atau siswa tidak hanya menerima belaka.

Berdasarkan hasil observasi dan wawancara yang dilakukan di SMPN 3 Gunungsari dengan guru mata pelajaran diperoleh informasi bahwa pada pembelajaran IPA sebelumnya jarang diadakan suatu pembelajaran yang berpusat pada siswa. Metode yang paling sering digunakan dalam proses pembelajaran adalah diskusi informasi, dimana dalam metode ini guru lebih aktif dalam kegiatan pembelajaran daripada siswa, dimana siswa di kelas hanya mendengar, mencatat, dan mengahafal. Hal ini disebabkan karena pembelajaran masih didominasi oleh guru, dan peserta didik hanya menerima informasi yang dijelaskan oleh gurunya saja, sehingga pembelajaran di dalam kelas berlangsung secara monoton dan menyebabkan siswa menjadi kurang tertarik untuk mengikuti pembelajaran sehingga sebagian besar. siswa mengobrol dengan teman sebangkunya dan kadangkala mengerjakan tugas mata pelajaran lain.

Pembelajaran IPA di sekolah sebaiknya : (1) memberikan pengalaman pada peserta didik, (2) menanamkan pada peserta didik pentingnya pengamatan empiris dalam menguji suatu pertanyaan ilmiah (hipotesis), (3) latihan berpikir kauntitatif yang mendukung kegaiatan belajar matematika, yaitu sebagai penerapan matematika pada masalah-masalah yang berkaitan dengan peristiwa alam,(4) memperkenalkan dunia teknologi melalui kegaiatn kreatif dalam kegaiatan perancangan dan pembuatan alat-alat sederhana maupun penjelasan berbagai gejala dan kemampuan IPA dalam menjawab berbagai masalah [6].

Oleh sebab itu, untuk mengatasi permasalahan tersebut dibutuhkan suatu alternatif strategi pembelajaran yang dapat meningkatkan minat dan motivasi belajar siswa, serta dapat melatih kemampuan berpikir kritis, ilmiah dan terampil dalam memecahkan suatu masalah sehingga pembelajaran berorientasi pada siswa bukan hanya pada guru saja. Salah satu strategi pembelajaran tersebut adalah strategi pembelajaran discovery.

Langkah-langkah strategi pembelajaran discovery yang akan dilakukan adalah sebagai berikut: (1) menganalisis kebutuhan siswa dengan cara menghadapkan fenomena yang akan berkaitan dengan IPA, (2) memberikan penjelasan singkat tentang prinsip-prinsip, pengertian, konsep-konsep dan generalisasi yang akan dipelajari, (3) siswa dihadapkan pada persoalan atau fenomena yang berhubungan dengan IPA, (4) siswa dibimbing mengamati dan memahami fenomena sesuai dengan IPA tersebut dan siswa dimotivasi untuk mengajukan pertanyaan-pertanyaan yang berkaitan dengan situasi IPA, (5) membantu dalam penyediaan alat dan bahan yang akan digunakan dalam proses penemuan, (6) memotivasi siswa untuk mengajukan dugaan dan menemukan gagasan-gagasan awal melalui tanya jawab, (7) memotivasi siswa untuk menemukan informasiinformasi yang diperlukan melakukan analisis (self analysis), (8) memuji dan membesarkan siswa yang bergiat dalam proses penemuan, dan (9) membantu 
siswa untuk menyimpulkan konsep-konsep yang sedang dipelajari [7].

Berdasarkan latar belakang tersebut, maka tujuan dalam penelitian ini adalah untuk mengetahui pengaruh strategi pembelajaran discovery terhadap kemampuan berpikir kritis iswa pada mata pelajaran IPA di SMPN 3 Gunungsari tahun ajaran 2013/2014.

\section{METODE PENELITIAN}

Jenis penelitian ini adalah eksperimen semu (quasi experiment). Desain penelitian yang digunakan adalah nonequivalent control group design. Penelitian ini dilaksanakan di SMPN 3 Gunungsari di kelas VIII semester ganjil tahun ajaran 2014/2015. Populasi dalam penelitian ini adalah seluruh peserta didik kelas VIII yang terbagi dalam lima kelas, sampel ditentukan dengan teknik cluster random sampling dan diperoleh kelas VIII A sebagai kelas eksperimen yang diberikan pembelajaran dengan strategi pembelajaran discovery dan kelas VIII B sebagai kelas kontrol yang diberikan pembelajaran dengan metode ceramah dan diskusi. Materi yang diajarkan dalam penelitian ini adalah struktur jaringan tumbuhan.

Variabel bebas dalam penelitian ini adalah strategi pembelajaran discovery dan variabel terikatnya adalah kemampuan berpikir kritis. Instrumen yang digunakan berupa tes essay yang telah valid dan reliabel sebanyak 8 soal, lembar observasi aktivitas siswa, dan lembar observasi aktivitas guru. Analisis uji hipotesis menggunakan uji-t.

\section{HASIL}

\section{Hasil Belajar Kognitif}

Berdasarkan hasil post-test pada akhir pembelajaran pada kedua kelas yaitu kelas eksperimen dan kelas kontrol. Pada kelas eksperimen diperoleh nilai tertinggi 90 dan nilai terendah 65 , dengan nilai rata-rata 73,7 , sedangkan hasil post-test pada kelas kontrol diperoleh nilai tertinggi 83 dan nilai terendah 50, dengan nilai ratarata 65,8. Pada hasil belajar kognitif dilakukan analisis ketuntasan belajar perorangan dan klasikal. Ketuntasan belajar perorangan tercapai apabila nilai siswa $\geq 73$ (KKM yang telah ditetapkan oleh sekolah). Hasil analisis ketuntasan belajar klasikal pada kelas eksperimen mencapai 50\%, sedangkan pada kelas kontrol mencapai 28,60\% (Tabel 1).

\section{Penilaian Psikomotorik}

Penilaian aspek psikomotorik dilakukan ketika pembelajaran discovery berlangsung dengan menggunakan lembar observasi yang terdiri dari 7 indikator. Hasil analisis penilaian psikomotorik siswa kelas eksperimen diperoleh nilai tertinggi 88 dan nilai terendah 68 dengan rata-rata 76,64, sedangkan pada kelas kontrol diperoleh nilai tertinggi 86 dan nilai terendah 62 dengan nilai ratarata 72,90 . Pada penilaian pskomotorik dilakukan analisis ketuntasan belajar perorangan (KKM $\geq 73$, yang telah ditetapkan oleh sekolah) dan ketuntasan belajar klasikal. Hasil analisis ketuntasan belajar klasikal pada kelas eksperimen mencapai 54,55\%, sedangkan pada kelas kontrol mencapai $52,38 \%$. Pada hasil belajar siswa untuk aspek psikomotorik dengan menggunakan strategi pembelajaran discovery menunjukkan hasil yang lebih tinggi dibandingkan dengan kelas kontrol yang menggunakan pembelajaran ceramah dan diskusi. Hasil nilai aspek psikomotorik terangkum pada Tabel 2.

Tabel 1. Nilai Post-test Kemampuan Berpikir Kritis Siswa

\begin{tabular}{|c|c|c|}
\hline \multirow{3}{*}{ Komponen } & \multicolumn{2}{|c|}{ Hasil Penilaian Post- } \\
\hline & \multicolumn{2}{|c|}{ Kelas } \\
\hline & Eksperi & Kontrol \\
\hline$\sum$ siswa & 22 & 21 \\
\hline $\bar{\sum}$ siswa yang & 11 & 6 \\
\hline$\sum \quad$ siswa yang & 11 & 15 \\
\hline Nilai tertinggi & 90 & 83 \\
\hline Nilai terendah & 65 & 50 \\
\hline Rata-rata & 73,7 & 65,8 \\
\hline$\% \quad$ Ketuntasan & $50 \%$ & $28,6 \%$ \\
\hline
\end{tabular}

Tabel 2. Nilai Aspek Psikomotorik Siswa

\begin{tabular}{lcc}
\hline \multirow{2}{*}{ Komponen } & \multicolumn{2}{c}{ Hasil Penilaian } \\
\cline { 2 - 3 } & \multicolumn{2}{c}{ Kelas } \\
$\sum$ siswa & 22 & 21 \\
$\sum \quad$ siswa $\quad$ yang & 12 & 11 \\
$\sum$ siswa yang tidak & 9 & 10 \\
Nilai tertinggi & 88 & 86 \\
Nilai terendah & 68 & 62 \\
Rata-rata & 76,64 & 72,90 \\
\% $\quad$ Ketuntasan & $54,55 \%$ & $52,38 \%$ \\
\hline
\end{tabular}

\section{Penilaian Afektif}

Penilaian afektif dilakukan ketika pembelajaran discovery dilaksanakan, dengan cara memberikan lembar observasi kepada observer (Uswatun H.) yang terdiri dari 10 indikator. Hasil analisis penilaian afektif siswa kelas eksperimen diperoleh nilai tertinggi 93 dan nilai terendah 81 dengan rata-rata 85,59 , sedangkan pada kelas kontrol diperoleh nilai tertinggi 91 dan nilai terendah 80 dengan nilai rata-rata 85,33. Pada penilaian afektif juga dilakukan analisis ketuntasan belajar perorangan $(\mathrm{KKM} \geq 73)$ dan ketuntasan 
belajar klasikal . Hasil analisis ketuntasan belajar siswa pada kelas eksperimen dan kelas kontrol mencapai $100 \%$.

Hasil belajar siswa untuk aspek afektif dengan menggunakan strategi pembelajaran discovery menunjukkan perbedaan rata-rata yang tidak terlalu signifikan dengan kelas kontrol, dan ketercapaian ketuntasan belajar perorangan sama dengan ketuntasan belajar perorangan yang dicapai oleh kelas kontrol yang menggunakan pembelajaran ceramah dan diskusi. Hasil nilai aspek afektif terangkum pada Tabel 3 .

Data hasil belajar siswa pada ketiga ranah penilaian yaitu kognitif, afektif dan psikomotorik setelah dirata-ratakan baik pada kelas eksperimen maupun kelas kontrol, diperoleh nilai tertinggi 90 dan nilai terendah 74 pada kelas eksperimen, dengan nilai rata-rata 78,64 , sedangkan pada kelas kontrol, diperoleh nilai tertinggi 86 dan nilai terendah 62 dengan nilai rata-rata 72,90. Pada hasil belajar siswa dilakukan analisis ketuntasan belajar perorangan $(\mathrm{KKM} \geq 73)$ yang telah ditetapkan oleh sekolah dan ketuntasan belajar klasikal. Persentase ketuntasan belajar klasikal pada kelas eksperimen mencapai $100 \%$, sedangkan pada kelas kontrol mencapai 52,38\% (Tabel 4). Tabel 4 menunjukkan bahwa rata-rata hasil belajar siswa kelas eksperimen lebih tinggi dibandingkan dengan nilai siswa pada kelas kontrol. Ini berarti bahwa strategi pemelajaran discovery berpengaruh terhadap hasil belajar siswa.

\section{Data Aktivitas Guru}

Data aktivitas guru dalam proses belajar mengajar di kelas bersumber dari hasil pengamatan oleh observer terhadap guru yang bersangkutan dengan mengisi lembar observasi yang telah ditentukan. Berdasarkan aktivitas guru baik pada kelas eksperimen maupun pada kelas kontrol guru
Tabel 3. Nilai Aspek Afektif Siswa

\begin{tabular}{lcc}
\hline \multirow{2}{*}{ Komponen } & \multicolumn{2}{c}{ Hasil Penilaian } \\
\cline { 2 - 3 } & \multicolumn{2}{c}{ Kelas } \\
$\sum$ siswa & sperimen & Kontrol \\
$\sum$ siswa yang tuntas & 22 & 21 \\
$\sum$ siswa yang tidak & - & 21 \\
Nilai tertinggi & 93 & - \\
Nilai terendah & 81 & 81 \\
Rata-rata & 85,59 & 85,33 \\
$\%$ Ketuntasan & $100 \%$ & $100 \%$ \\
\hline
\end{tabular}

Tabel 4 : Hasil Belajar Siswa Pada Kelas Kontrol dan Kelas Eksperimen

\begin{tabular}{lcc}
\hline \multirow{2}{*}{ Komponen } & \multicolumn{2}{c}{ Hasil Penilaian } \\
\cline { 2 - 3 }$\sum$ siswa & \multicolumn{2}{c}{ Kelas } \\
ksperimen & ontrol \\
N siswa yang & 22 & 21 \\
N siswa yang tidak & 22 & 11 \\
Nilai tertinggi & - & 10 \\
Nilai terendah & 90 & 86 \\
Rata-rata & 74 & 62 \\
$\%$ Ketuntasan & 78,64 & 72,90 \\
\hline
\end{tabular}

sudah melakukan semua indikator yang telah ditentukan pada lembar observasi dengan baik. Hal ini sesuai dengan kriteria yang menunjukkan bahwa guru sudah melakukan kegiatan pembelajaran di kelas secara baik dan baik sekali. Data aktivitas guru kelas eksperimen dan kelas kontrol dapat terangkum pada Tabel 5.

Tabel 5. Data Aktivitas Guru

\begin{tabular}{ccccc}
\hline \multirow{2}{*}{ Komponen } & \multicolumn{2}{c}{ Kelas eksperimen } & \multicolumn{2}{c}{ Kelas kontrol } \\
\cline { 2 - 5 } & Pertemuan I & Pertemuan II & Pertemuan I & Pertemuan II \\
Skor total & 52 & 66 & 51 & 55 \\
Skor rata-rata & 0,72 & 0,92 & 0,71 & 0,76 \\
Persentase & $72 \%$ & $92 \%$ & $71 \%$ & $76 \%$ \\
Kriteria & Baik & Baik sekali & Baik & Baik sekali \\
\hline
\end{tabular}

\section{PEMBAHASAN}

Kemampuan berpikir kritis meliputi
kemampuan mensintesis, menganalisis,
memecahkan masalah, menilai dan mengevaluasi,
mengingat dan menghubungkan dengan
pembelajaran yang terdahulu, dan kemampuan
menarik kesimpulan. Penilaian aspek tersebut untuk

mengetahui kemampuan berpikir kritis siswa selama pembelajaran. Hasil kemampuan bepikir kritis siswa mengalami peningkatan baik pada kelas eksperimen maupun kelas kontrol.

Perbedaan peningkatan kemampuan berpikir kritis siswa pada kelas eksperimen dan kelas kontrol dikarenakan adanya perbedaan 
strategi pembelajaran yang digunakan dikedua kelas tersebut. Pada kelas eksperimen strategi yang digunakan adalah strategi pembelajaran discovery dimana dalam strategi pembelajaran ini memberikan dampak positif terhadap siswa. Strategi pembelajaran ini mampu memberikan kesempatan bagi siswa untuk lebih aktif dalam proses pembelajaran. Siswa didorong untuk mempunyai pengalaman dan melakukan percobaan yang memungkinkan mereka menemukan prinsipprinsip atau pengetahuan bagi dirinya. Proses pembelajaran tidak lagi terpusat pada guru, melainkan pada masing-masing siswa itu sendiri (student centred). Melalui strategi pembelajaran discovery ini, siswa langsung terlibat pada proses pembelajaran, menemukan prinsip-prinsip, dan jawaban lewat percobaan atau praktikum.

Materi struktur dan fungsi jaringan batang terdapat banyak materi yang bersifat abstrak, sehingga membuat siswa cukup kesulitan untuk memahami materi struktur dan fungsi jaringan batang tersebut. Menurut kajian psikologi [8], anak lebih mudah mempelajari hal yang konkret ketimbang yang bersifat abstrak. Pembelajaran IPA yang bersifat abstrak akan lebih mudah dipelajari ketika berawal dari sesuatu yang konkret atau nyata. Ini sesuai dengan pelaksanaan pembelajaran discovery yang didukung dengan praktikum yang dilakukan siswa dengan bantuan alat percobaan sehingga pembelajaran menjadi lebih efektif dan siswa dapat belajar untuk menemukan sendiri. Adanya bantuan alat percobaan ini membuat materi struktur dan fungsi jaringan batang yang bersifat abstrak semakin mudah dipahami karena siswa dapat mempunyai pengalaman dan melakukan percobaan yang memungkinkan mereka menemukan prinsip-prinsip atau pengetahuan bagi dirinya. Keaktifan siswa dalam melakukan percobaan dapat melatih kemampuan berpikir kritis siswa. Pada proses pembelajaran discovery siswa juga mengalami dua pengalaman belajar yaitu pengalaman mental dan pengalaman sosial. Pengalaman mental diperoleh dari indra pendengaran dan penglihatan, informasi yang didapatkan berdasarkan apa yang didapatakan berdasarkan indra pendengaran diperoleh dari penjelasan yang diberikan guru sedangkan indra pengelihatan berasal dari penemuan siswa itu sendiri.

Penemuan tersebut akan selalu diingat oleh siswa daripada harus mendengar penjelasan dari guru. Pengalaman sosial diperoleh saat siswa berinteraksi dengan teman sekelompok waktu melakukan percobaan sehingga mereka lebih terlibat aktif dalam proses pembelajaran. Pembelajaran discovery menimbulkan rasa keingin tahuan siswa sebab dalam pelaksanaannya siswa diajak untuk menemukan sendiri berbagai teori, hukum, dan konsep dengan praktikum. Brunner dalam [9], yang menyatakan bahwa belajar penemuan mengakibatkan keingintahuan siswa, memberikan motivasi untuk bekerja terus sampai menemukan jawaban-jawaban. Dampak dari penemuan sendiri mempengaruhi hasil belajar siswa menjadi lebih baik. Hal ini sesuai pendapat Catharina dalam [10], mengatakan bahwa hasil belajar itu tidak disebabkan oleh kemampuan internal manusia, tetapi karena faktor keingintahuan manusia yang menimbulkan respon. Menurut Sudrajat dalam [11], menyatakan bahwa keuntungan dari pendekatan discovery learning adalah, 1). Memacu keingintahuan siswa, 2). Meningkatkan motivasi, 3).Belajar mandiri dalam memecahkan masalah, 4). Belajar berfikir kritis dengan menganalisis dan memanipulasi informasi.

Berbeda dengan kelas eksperimen, kelas
kontrol menggunakan pembelajaran direct instruction dengan metode ceramah dan diskusi. Pada pembelajaran direct instruction dengan metode diskusi dan ceramah siswa diberi LKS (Lembar Kerja Siswa) untuk didiskusikan dengan masing-masing teman kelompoknya. Pada kelas kontrol sebelum siswa berdiskusi, guru memberi gambaran sedikit tentang materi struktur dan fungsi jaringan batang. Struktur dan fungsi jaringan batang yang di dalamnya banyak materi yang bersifat abstrak membuat siswa kelas kontrol cukup kesulitan untuk memahami materi struktur dan fungsi jaringan batang tersebut. Siswa cukup mengalami kesulitan saat berdiskusi dengan kelompok untuk menjawab soal-soal yang ada pada lembar kerja siswa, karena pada kelas kontrol tidak dilakukan praktikum untuk lebih memperjelas apa yang sudah dijelaskan oleh gurunya. Siswa dalam menjawab hanya bisa membayangkan dan mengingat penjelasan yang didengar dari gurunya. Masalah tersebut yang menyebabkan perbedaan nilai rata-rata berpikir kritis kelas kontrol lebih rendah dari rata-rata berpikir kritis kelas eksperimen. Hal ini membuktikan bahwa pembelajaran discovery, memberi pengalaman belajar siswa sehingga hasil belajar siswa juga menjadi lebih baik.

Kelas eksperimen mengalami peningkatan hasil belajar yang lebih baik dibandingkan dengan kelas kontrol. Hal ini sesuai dengan penelitian yang dilakukan Junaendra[12], yang menyatakan bahwa penerapan metode discovery dapat meningkatkan prestasi belajar biologi siswa SMP Negeri 19 Mataram tahun ajaran 2008/2009.

Penerapan strategi pembelajaran discovery learning tidak hanya berdampak pada hasil belajar aspek kognitif saja, akan tetapi juga berdampak pada aspek afektif dan psikomotor setelah diberi perlakuan. Hasil penelitian pada aspek afektif memperlihatkan nilai yang lebih tinggi pada kelas eksperimen dengan menggunakan strategi 
pembelajaran discovery dibandingkan dengan kelas kontrol yang menggunakan pembelajaran konvensional. Hal ini sesuai dengan pendapat Arifin dalam [15], yang menyatakan bahwa, metode ceramah dapat mengahalangi respon siswa, membatasi daya ingat serta cendrung membosankan bagi siswa. Selain itu juga dengan diterapkannya metode ini dapat mengakibatkan minat dan partisipasi siswa menjadi berkurang, akibatnya kondisi belajar menjadi tidak efektif. Berdasarkan hal tesebut dapat disimpulkan bahwa pada kelas eksperimen nilai afektifnya lebih tinggi dibandingkan dengan nilai afektif pada kelas kontrol.

Proses pembelajaran dengan menggunakan strategi pembelajaran discovery, juga memperlihatkan adanya dampak positif pada aspek psikomotorik siswa. Data yang diperoleh menunjukkan hasil belajar psikomotorik kelas eksperimen lebih baik dibandingkan dengan hasil belajar psikomotorik kelas kontrol. Menurut Zulhelmi [16], salah satu pendekatan pembelajaran yang cocok untuk menerapkan penilaian psikomotor dan melihat respon siswa dalam pembelajaran sains adalah penemuan terbimbing (Guided Discovery). Pendekatan pembelajaran ini memberikan peluang bagi aktifitas kelas yang berpusat pada siswa (student centered) dan memungkinkan siswa belajar memanfaatkan berbagai sumber belajar yang tidak hanya menjadikan guru sebagai satu-satunya sumber belajar.

Perbedaan hasil belajar antara kelas eksperimen dan kelas kontrol semakin diperkuat melalui uji hipotesis. Uji t-test polled varians digunakan untuk mengetahui apakah terdapat perbedaan peningkatan kemampuan berpikir kritis yang signifikan antara kelas eksperimen dan kelas kontrol. Berdasarkan hasil uji-t menggunakan taraf kepercayaan $5 \%$ dan $\mathrm{dk}=41$ diperoleh harga $\mathrm{t}_{\text {tabel }}=$ 2,02 sedangkan harga $t_{\text {hitung }}=3,21$. Harga thitung $>$ $t_{\text {tabel }}(3,21>2,02)$, sehingga Ho ditolak dan $\mathrm{Ha}$ diterima. Analisis uji-t ini juga dilakukan pada nilai rata-rata hasil belajar yang diperoleh siswa yaitu hasil belajar kognitif (kemampuan berpikir kritis), psikomotorik dan afektif yang menunjukkan bahwa $t_{\text {hitung }}$ lebih besar dari $t_{\text {tabel }}(3,22>2,02)$. Berdasarkan hasil analisis tersebut dapat disimpulkan bahwa strategi pembelajaran discovery berpengaruh terhadap kemampuan berpikir kritis siswa. Dengan demikian, rata-rata kemampuan berpikir kritis siswa pada kelas eksperimen meningkat secara signifikan.

Pelaksanaan pembelajaran discovery dalam penelitian mengalami beberapa hambatan atau kendala diantaranya adalah siswa belum kurang terampil dalam melaksanakan praktikum. Hal ini menyebabkan dalam proses pembelajaran banyak waktu yang terbuang. Keterbatasan alat yang dimiliki oleh laboratorium di sekolah tersebut juga mempengaruhi jumlah siswa dalam satu kelompok sehingga kelompok yang tidak mendapatkan alat dalam proses praktikum terpaksa harus bergabung dengan kelompok yang mendapatkan alat praktikum, yang seharusnya kelompok yang tadi jumlahnya empat sampai lima siswa menjadi enam sampai tujuh siswa. Jumlah tersebut menyesuaikan jumlah alat yang tersedia. Jumlah siswa yang terlalu banyak dalam satu kelompok membuat ada sebagian anggota yang tidak membantu pada saat praktikum dan membuat suasana menjadi gaduh, sehingga kerjasama siswa dalam kelompok menjadi kurang optimal. Menurut Slavin [13], jumlah siswa dalam satu kelompok yang ideal beranggotakan empat orang. Kelompok yang berjumlah empat orang memudahkan siswa bekerja sama dan menguasai materi yang dipelajari. Keaktifan melakukan eksperimen dalam kelompok sesuai dengan pendapat Wenning dalam [14], yaitu kerja kelompok akan memberikan kesempatan kepada siswa untuk bekerjasama dalam kelompoknya dengan nyaman tanpa merasa malu dan bebas mengeluarkan ide-idenya tanpa rasa takut dikritik.

Berdasarkan analisis data aktivitas guru dapat diketahui bahwa persentase peningkatan aktivitas guru sangat tinggi. Hal ini disebabkan karena hampir semua indikator sudah dilaksanakan dengan baik. Strategi yang diterapkan oleh guru pada kelas eksperimen adalah pembelajaran discovery dimana dalam pembelajaran ini siswa lebih aktif dan diberikan kesempatan untuk menemukan jawaban dari masalah-masalah yang berisi konsep-konsep dan dihadirkan oleh guru dalam bentuk percobaan-percobaan. Peran guru disini hanya berperan sebagai mediator, motivator dan fasilitator bagi siswa dalam kegiatan diskusi kelompok. Analisis data aktivitas guru pada kelas kontrol diketahui persentase peningkatan aktivitas guru dari pertemuan I ke pertemuan berikutnya sangat rendah.

Ketuntasan belajar siswa pada kelas eksperimen yang diajarkan menggunakan pembelajaran discovery lebih tinggi daripada ketuntasan belajar kelas kontrol. Hal ini menunujukkan bahwa melalui strategi pembelajaran discovery siswa berperan secara lebih aktif dan melibatkan seluruh kemampuan yang dimiliki oleh siswa sehingga tingkat pemahaman siswa terhadap suatu materi menjadi lebih baik, dengan demikian tingkat pencapaian siswa menjadi lebih optimal.

\section{KESIMPULAN}

Berdasarkan hasil penelitian dan pembahasan, dapat disimpulkan bahwa strategi pembelajaran discovery berpengaruh terhadap kemampuan berpikir kritis siswa pada mata 
pelajaran IPA kelas VIII di SMPN 3 Gunungsari Tahun Ajaran 2014/2015

\section{DAFTAR PUSTAKA}

[1] Hamzah. 2009. Mengelola Kecerdasan Dalam Pembelajaran. Jakarta: Bumi Aksara.

[2]Khoiru, Amri, Elisah. 2011. Strategi Pembelajaran Beroroentasi KTSP. Jakarta :PT. Prestasi Pustaka Karya.

[3]Sopiatin, P. 2010. Manajemen Belajar Berbasis Kepuasan Siswa. Bandung: Ghalia Indonesia.

[4]Mulyati, I. 2009. Penerapan Pembelajaran Kooperatif Numbered Head Toogether (NHT) Pada Pokok Bahasan Himpunan Sebagai Upaya Untuk Meningkatkan Aktivitas Dan Prestasi Belajar Siswa Kelas $\quad$ VII $\quad G$ SMPN 9 Mataram Tahun Ajaran 2006/2007. Mataram: Universitas Mataram

[5]Farida, Ida . 2012. Penerapan Metode Discovery Dalam Pembelajaran Biologi Untuk Meningkatkan Hasil Belajar Biologi Siswa Kelas VIII Mts AL- Aziziyah Putra Kapek Gunung Sari Tahun Pelajaran 2011/2012. Mataram: Universitas Mataram.

[6]Trianto.2011.Model Pembelajarn Terpadu.: Konsep, Strategi dan Implementasinya dalam KTSP. Jakarta: Bumi Aksara.

[7]Piamin, Siagan. 2012. Pengaruh Strategi Pembelajaran Dan Gaya Belajar Terhadap Hasil Belajar IPA. Jurnal Teknologi Pendidikan. (Online) : http://Digilib.Unimed.Ac.Id/Public/Uni med- Article-25767

Sahat $\% 20$ siagian $\% 20$ -

\%20paimin\%20tanjung-16.Pdf.Diakses Tanggal 24 November 2014.

[8]Santyasa,I. W. 2007. Landasan Konseptual Media Pembelajaran. Makalah. Universitas Pendidikan Ganesha.

[9]Farida, Ida . 2012. Penerapan Metode Discovery Dalam Pembelajaran Biologi Untuk Meningkatkan Hasil Belajar Biologi Siswa Kelas VIII Mts ALAziziyah Putra Kapek Gunung Sari Tahun Pelajaran 2011/2012. Mataram : Universitas Mataram

[10]Eko, Sunyoto, Wiyanto. 2012. Penerapan Model Pembelajaran Materi Pemantulan Cahaya Untuk Meningkatkan Berpikir Kritis. Unnes Physics Education Journal 1 (1). (Online) http://journal.unnes.ac.id/sju/inde x.php/upej/article/download/768/793, Diakses tanggal 3 Desember 2014.

[11]Zulhelmi. 2009. Penilaian Psikomotor dan Respon Siswa Dalam Pembelajaran

Sains Fisika Melalui Penerapan Penemuan Terbimbing di SMP Negeri Pekanbaru. Jurnal Geliga Sains 3 (2), 8-13. (Online):http://ejournal.unri.ac.id/inde x.php/JGS/article/download/300/294, Diakses tanggal 12 Desember 2014.

[12]Junaendra. 2009. Penerapan Metode Discovery dalam Meningkatkan Prestasi Belajar Biologi Siswa SMP Negeri 19 Mataram Tahun Ajaran 2008/2009.Mataram: Universitas Mataram.

[13]Slavin, R.E. 2010. Cooperatif Learning. Bandung : Nusa Bangsa.

[14] Syafi'i, Handayani, Khanafiah. 2014. Penerapan Question Based Discovery Learning Pada Kegiatan Laboratorium Fiskia Untuk Meningkatkan Keterampialan Sains. Unnes Physic Education Journal 3 (2). (Online) : http:/journal.unnes.ac.id/sju/index.php /upej , Diakses Tanggal 12 Desember 2014.

[15]Junaendra. 2009. Penerapan Metode Discovery dalam Meningkatkan Prestasi Belajar Biologi Siswa SMP Negeri 19 Mataram Tahun Ajaran 2008/2009.Mataram : Universitas Mataram.

[16]Zulhelmi. 2009. Penilaian Psikomotor dan Respon Siswa Dalam Pembelajaran Sains Fisika Melalui Penerapan Penemuan Terbimbing di SMP Negeri Pekanbaru. Jurnal Geliga Sains 3 (2), 8-13. 
